\title{
THE COLLEMBOLA OF LEBANON \\ AND WESTERN SYRIA \\ PART III FAMILY ISOTOMIDAE ${ }^{1}$
}

\author{
By K. Christiansen \\ Grinnell College, Grinnell, Iowa
}

The work herein described was done under N.S.F. Grant G 4563. I wish to gratefully acknowledge the work of my assistant, Jerry Tecklin, who did all of the preliminary sorting and most of the handling and mounting of the material here studied.

Relatively little has been known about the Isotomidae of the Syrian region. Until the work of Cassagnau and Delamare only a few of the more prominent epigeic forms had been described. With the above mentioned work the recorded species from the area were eight. In the present study four of these forms were recovered and two others were probably recovered. In addition 16 new records were established.

\section{Anurophorus coiffaiti Cassagnau \& Delamare Plate 8, figures 6, 7}

Anurophorus coiffaiti P. Cassagnau \& Cl. Delamore, 1951 Biospeologica $75: 377,378$.

This species was the first of the genus to be described from Western Syria. The specimens at hand agree well with the illustrations and figures given by Delamare and Cassagnau. The P.A.0. (see figure 7) is characteristically oval with a definite indentation or indication of a listel at least on the forward margin. The abdominal thickenings chararacteristic of the species vary a great deal but some indication of these can be seen even in the youngest specimens. In some forms these fuse into a single large tuberclelike projection. The sense organ of the third antennal segment usually has only two short setae between the

1 Published with the aid of a grant from the Museum of Comparative Zoology at Harvard College. 
guard rods instead of three as indicated in the describers' illustration.

The species appears in the moist regions, largely in the mountains. Type locality Antelias Lebanon, x 9-51. Other captures: LEBANON: Ain Zhalte Cedars, 177 M., XI '52; B'charra Cedars, 1900 M. v '52; between Dhour Schweir and Bikfaya, VIII '53; Nahr Array between B'kassine and Jezzine, 800 M.; Wadi Jahnam (N.W. Tripoli Prov.), vII 31 '52; Bikfaya vII '53. SYRIA: Latakia Oak Grove, just below Turkish border, vIII '53.

\section{Anurophorus asfouri, n. sp.}

Plate 8, figures 1-5

Body subcylindrical with deep constrictions between segments. Unpigmented prothorax much wrinkled and about $1 / 2$ as long as mesonotum. Clothing of body of relatively uniform short smooth acuminate setae, mostly curved with slightly longer straight setae on last three abdominal segments. Intersegmental membranes clearly demarcated except for fifth and sixth abdominal segments, which are solidly fused. Pigment blue, in scattered scabrous patches over head, antennae, and tergites. Intersegmental membranes and legs pale. Eyes eight per side on a medially constricted eye patch. Antennal apex with a large bilobed bulb set in a deep pit. Fourth antennal segment clothed

\section{Explanation of Plate 8}

Figures 1-5: Anurophorus asfouri n. sp. 1. Habitus, paratype, seen from above and slightly to one side, setae omitted, $90 \times$. 2. Tip of fourth antennal segment, paratype, $1000 \times$. 3. Hind foot, paratype,1000 $\times$. 4. Third antennal segment "sense" organ, paratype, $1000 \times$. 5. Eyes and P.A.o. right side, paratype, $700 \times$. Figures 6 and 7: A. coiffaiti. 6 . Tip fourth antennal segment, specimen from between Dhour Shweir and Bkfaya Lebanon, $1000 \times$. 7. Anterior portion eye and P.A.o. Same specimen as above, $1000 \times$. Figures 8-13: Ballistura levantina n. sp. 8. Habitus, setae and pigment omitted, paratype, $40 \times$. 9. Hind foot, paratype, $1200 \times$. 10. Inner margin of apex of fourth antennal segment, paratype, $1200 \times$. 11. Inner part base of left dens showing dental projections, paratype, $1200 \times .12$. Right mucro seen from above and slightly to one side, paratype, $1200 \times$. 13. Left mucro, side view, holotype, $380 \times$. 


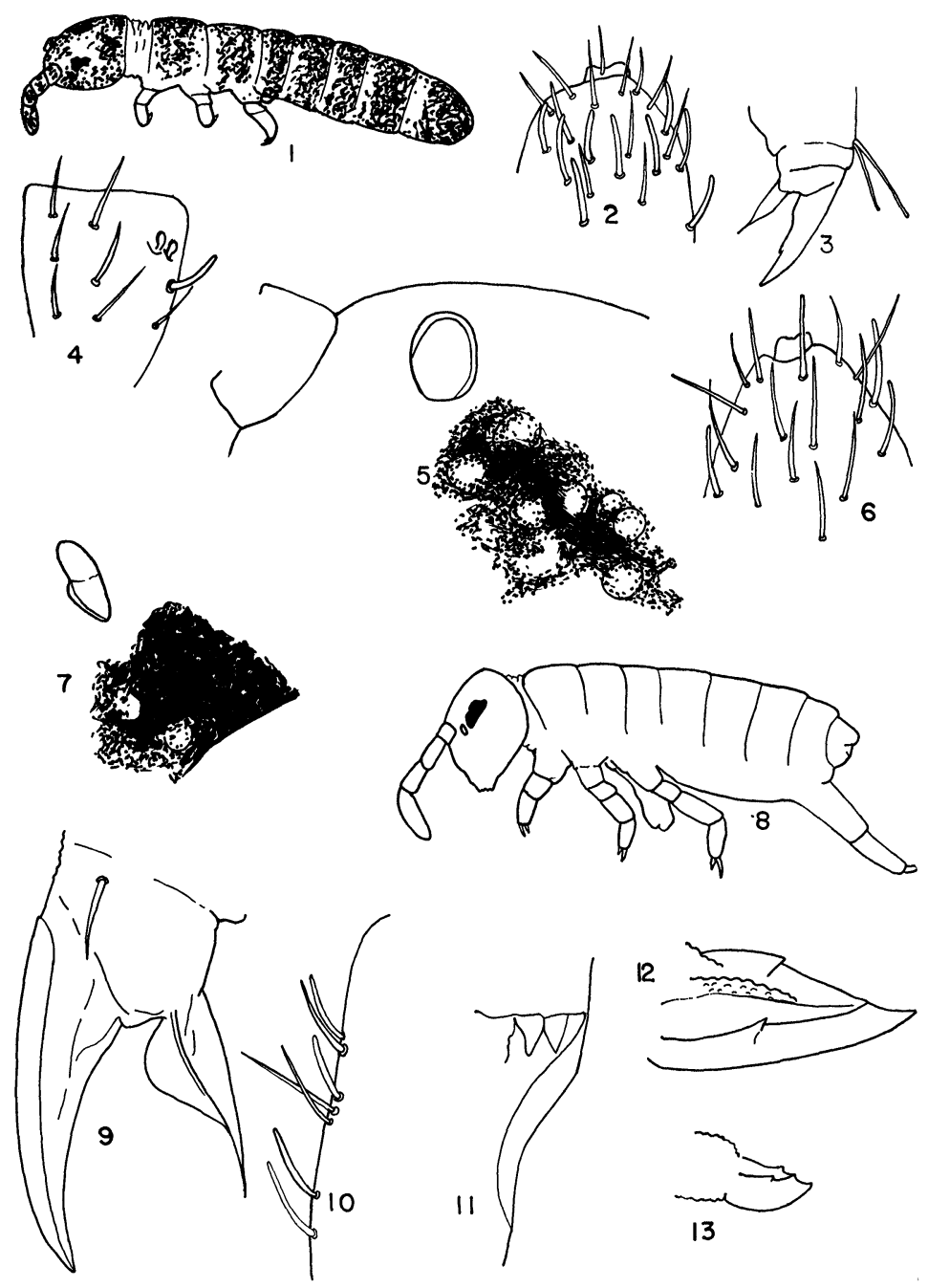

$$
\text { Christiansen - Collembola }
$$


with a mixture of curved and straight acuminate setae, and a number of slightly curved blunt "sensory" setae. The latter type form about one third of the clothing of the apical half of the segment. Third segment clothed with a number of curved acuminate setae, and in addition six blunt setae as follows: on the dorsal surface two long rods enclose between them two short oval knobs (about one third as long as the rods); on the ventral surface there are two additional curved rods about one half as long as the dorsal ones. Second and first antennals segments each with a circlet of acuminate setae. P.A.o. broadly oval and more than twice as large as the largest eye. Eyes eight per side with eyes $\mathrm{D}, \mathrm{H}$, and $\mathrm{E}$, being smaller than the remainder. Integument granulate save for the last two abdominal tergites which are finely reticulate. Legs with tibiotarsi subsegmented. Unguis without lateral teeth but with an extremely small inner tooth. Empodial appendage lanceolate, slightly less than half as long as unguis, and lacking any apical bristle. Unguis with three weakly clavate tenent hairs, the median being strikingly longer than the remainder.

The description of this form brings to four the number of species of Anurophorus having the fifth and sixth abdominal segments fused into a single mass. Although these species are generally similar they may be readily separated on the basis of the characteristics listed below:

Separation of Species of Anurophorus having THE Fifth AND Sixth Abdominal Segments Fused

Organ

Species

A. konseli

A. asfouri

$A$. oredonensis

A. coiffaiti
P.A.O.

broadly oval

broadly oval

narrow, indented

narrow, indented eyes/side ungual tooth

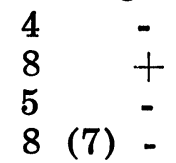

In addition to these, special characteristics such as the abdominal thickenings of $\mathrm{A}$. coiffati and the antennal chaetotaxy can be used for additional separation.

Type locality: Kammouha LEBANON (25 specimens), 1900 M., VII 19 '52; also taken from Latakia, SYRIA, oak grove just below Turkish border, vIII '53. 
Tetracanthella pilosa Schött

Tetracanthella pilosa Schött, 1891. Ent. Tidskr. 12:191.

The specimens at hand agree with the descriptions and figures in Stach quite well. The only small difference noted was that the furcula was relatively longer. The species is quite rare in the region under consideration. It has been taken from: LEBANON: Ain Z'Halte Cedars, above forest, XI' 52 ; SYRIA : Pine Forest, Northern Latakia, VIII '53.

Folsomides americanus Denis

Folsomides americanus Denis 1931. Bul. Lab. Zool. Portici 26:69-170.

I have nothing to add to the comments of Cassagnau and Delamare (op. cit.) concerning this species except that comparison with North American material shows it to be identical with the specimens at hand. This material had previously been identified as Folsomides parvus. The species is widespread and abundant through the lowland and lower mountain regions of the area under consideration. Taken from LEBANON: Beirut, campus American University, many dates from 1951 through 1953; Souk el Gharb, VIII '53, between Kfardebiene \& Bskinta, v '53; Beit ed Dine, XI '53; Saida, XI '51; $14 \mathrm{Km}$. South of Saida, XI '53; 2 km. East of Rayak, VII '52; Farayha, v '53. SYRIA Latakia, oak grove just below Turkish border, vIII '53.

\section{Folsomia}

This genus is the best represented Isotomid genus in the area. There are probably five species occuring in the area, and the nature of the population isolation and variation within several of the species concerned merits a great deal more study. Cassagnau and Delamare (op. cit.) describe one new species and mention the capture of three single specimens they determined as Folsomia ksenemani, I feel certain that these were in fact single-eyed specimens of the same species I have identified as $F$. penicula Bagnall. For this reason I have not included ksenemani in the list below. It is quite probable that larger series in each case would have shown the more typical four-eyed forms in each population.

Folsomia quadrioculata Tullberg

Isotoma quadrioculata Tullberg, 1871. Ofv. Kongl. Vet. Akadm. Forhandl. 27 (1) :143-155. 
A great deal has been written about the group of species related to the form named above. Out of this there has developed a welter of species: brevicauda, quadrioculata, manolachei, nana, microchaeta, penicula and multiseta. Further than this when we considered the excellent work of Agrell upon variation in eye number we can add to this group at least the one-eyed forms such as regularis, diplopthalmia, agrelli, ksenemani, pseudodiplopthalma, similis, and monopthalma. Most of these so-called species differ by very few characteristics, indeed often only by one. These are commonly chaetotaxy differences and there is not the slightest bit of evidence to deny the possibility that they represent single gene variations. Thus the differences seen could well represent in some cases balanced polymorphism, and in others ecotypical selection for a given gene. Further than this most of the species here mentioned have been studied at one time from a few relativley homogenous habitats and there is thus little opportunity to study the variation through a wide range of conditions. I wish to suggest that there is at present insufficient evidence to sort out accurately from the forms mentioned above more than a few forms and be able to say with any degree of assurance that they actually represent different species. The specimens studied below appear to be classifiable as two species, $F$. quadrioculata and $F$. penicula. If we accept this thesis, then it is possible to sort out the specimens at hand quite readily on the basis of the ventral manubrial chaetotaxy. If we sort them out thus, it appears that with few exceptions a given collection or sample is of one form or the other. If an attempt is made to sort out the populations on any other basis, this is not so and most samples are mixed. Further, in a statistical sense it is possible to sort out these two species upon about five additional characteristics; however, none of these shows very good correlation with the manubrial chaetotaxy. For purposes of illustrating the distribution of some of these characteristics through the population, a large number of specimens from twelve localities was sorted out to quadrioculata or penicula on a basis of the ventral manubrial setae. Fifteen specimens were chosen from each species and checked for a number of characteristics. The results are indicated below. 
Description of character

Eyes unequal in size

Largest setae posterior

margin head twice smallest

Brush-like mass long setae

(4-5 rows) at end abdomen

Gap of P.A.o. wider than lip

Dentes with median dorsal seta

$\begin{array}{cc}\begin{array}{c}\text { \% } \\ \text { quadrioculata } \\ \text { having }\end{array} & \begin{array}{c}\% \text { pe } \\ \text { hav }\end{array} \\ 47 & 86 \\ & \\ 33 & 100 \\ & \\ 73 & 100 \\ 93 & 47 \\ 47 & 93\end{array}$

Other differences examined (ex., angling P.A.o. dorsal chaetotaxy, occurence one-eyed forms, shape of mucro) showed even less differentiation, or differences so fine as to be impractical. In many populations of both species an occasional one-eyed form is to be found, and a few populations consist of such forms exclusively, without differing in any other visible respect from the four-eyed populations.

The net result of this is to indicate that in the region studied there are two forms separable upon a basis of their manubrial chaetotaxy. It is convenient to consider them as two species but it must be understood that the real nature of their genetic relationship has yet to be established.

In the Western Syrian region penicula is widely distributed throughout the Lebanese mountains and the coastal plain, whereas quadrioculata is largely limited to the higher elevations of the Lebanon Mountains.

Distribution of quadrioculata: LEBANON: Ain Z'Halte Cedars, 1700 M. vII '52 \& XI '52; between K'Fardebiene \& Beskinta, 1900 M., vI '53; Hadeth Cedars, 1700 M., vII '53 B'Charra Cedars, 1900 M., v '53; Barouk Cedars, 1700 M.. VI '53.

\section{Folsomia penicula Bagnall}

Folsomia penicula Bagnall 1939. Ent. Mo. Mag. $75: 56-59$.

Folsomia tetropthalma Gisin 1946. Mitt. Scweiz. Ent. Ges. 20:219. (NEW SYNONYMY).

Folsomia multiseta Stach 1947. Acta Monographica Polska Akademia umiejetnosci 138:172-177. (New Synonymy).

Penicula was described for forms having two pairs of eyes with the posteriormost pair smaller than the fore pair and having a brush-like mass of setae at the end of the abdomen. In addition to this the members of the species are 
characterized by having six or more ventral manubrial setae in adult animals. In 1946 Gisin pointed out that this species was probably identical with Kseneman's F. diplopthalma var. Tetropthalma. Since Kseneman had indicated that in his opinion this was a matter of population variation and thus not subspecific in rank, this name would fall under the category of "infrasubspecific form" according to the rules "A name given to any infrasubspecific form if elevated to subspecific or specific rank by a subsequent reviser shall rank in its new status for purposes of priority as from the date on which it was so elevated, and shall be attributed to the author by whom it was so elevated." Thus Folsomia tetropthalma becomes a junior synonym of F. penicula.

The species is extremely common in Lebanon and Syria, and in a variety of habitats. The specimens at hand display characteristics which destroy the separation shown between this species and multiseta by Stach (1947). The table below indicates how this species violates both sets of limitations: penicula acc. multiseta acc.

$$
\text { Stach Stach Leb. penicula }
$$

Ventral maubrial

setae

P.A.o./ommatidium

ventral setae on dens
$12-13$

$3.5-4$

12
$14-17$

4-5

16-22
$11-16$

$3.5-6$

$12-18$

In view of this I feel best to consider multiseta a synonym of the locally variable penicula.

\section{Explanation of Plate 9}

Figures 14-21: Isotomina salaymehi n. sp. 14. Habitus, specimen from Beirut, $90 \times$. 15. Tip of fourth antennal segment, paratype, $1200 \times$. 16. Chaetotaxy last two abdominal segments, side view, paratype, $600 \times$. 17. Eyes and P.A.o. Unusual specimen with complete division eye patch, paratype, $1200 \times$. 18. Eyes and edge P.A.o. showing normal condition, paratype, $600 \times$. 19. Right mucro, paratype,1100 $\times .20$. Abdominal "sensory" seta with neighboring normal seta, ptaarype, $1100 \times$. 21. Hind unguis, paraytpe, $1200 \times$. Figure 22-25: Vertagopus ciliatus n. sp. 22. Habitus (slightly distorted by mounting) paratype, $90 \times$. 23. Apex fourth antennal segment, holotype, $1200 \times$. 24 . Long ciliate setae of fifth and sixth abdominal segments, holotype, $1200 \times$. 25. Eyes and P.A.o. left side paratype, $1200 \times$. 

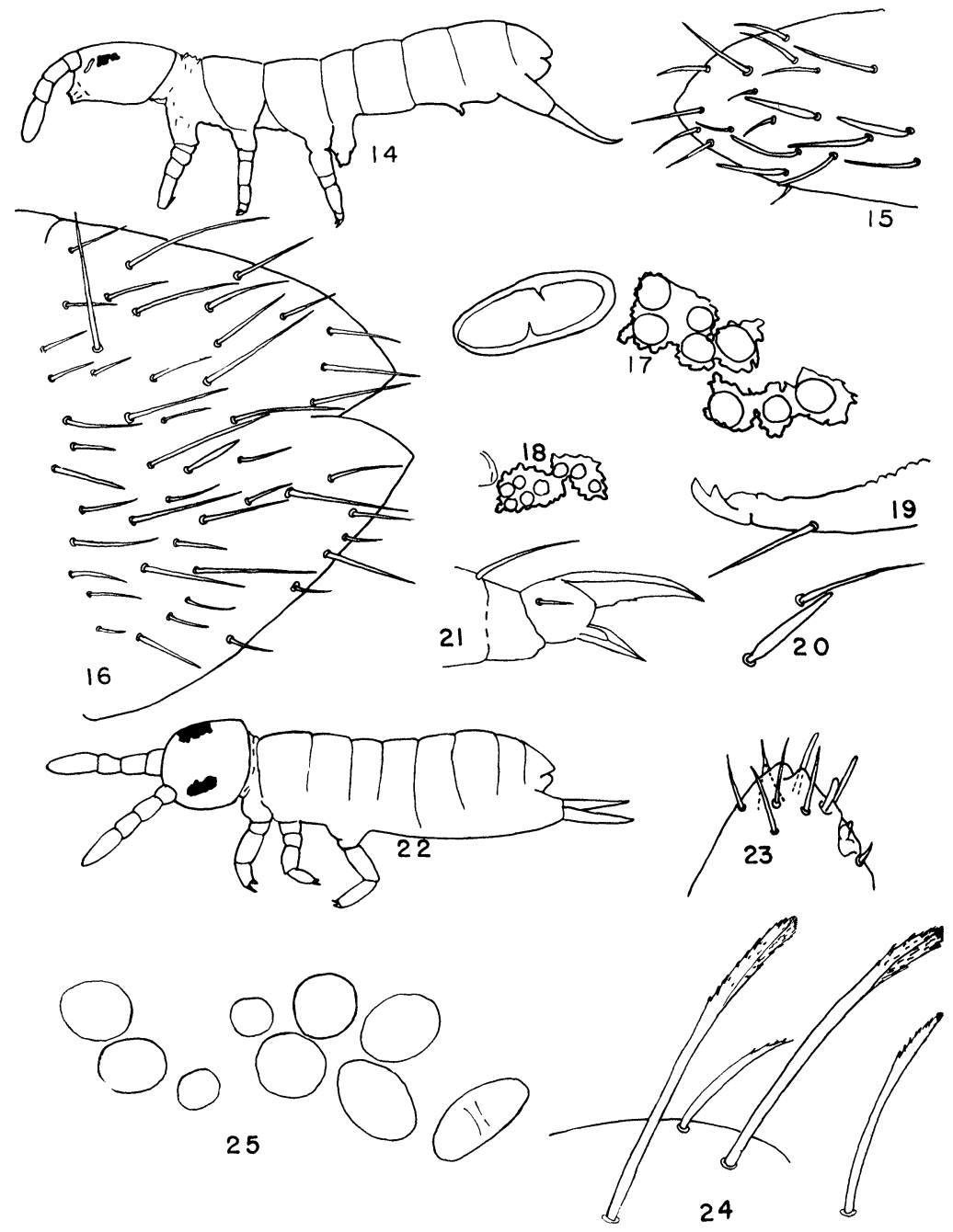

Christiansen - Collembola 
One last point which must be discussed is the variation in the number of eyes. Agrell, Kseneman, Stach and a number of other investigators have accepted the fact that the number of eyes in at least some species of Folsomia is varible. Gisin in 1946 has stated that this condition has not been proven for any species of the genus. Among the specimens I have identified as $F$. penicula are occasional specimens with a single pair of eyes, and in one case a specimen lacking eyes entirely. Beyond this, an occasional (2) small sample may consist of all one-eye paired forms. In all cases, and particularly where the four-eyed and twoeyed forms occurred in the same population, a slow, careful comparison was made between the two-eyed and foureyed forms and not the slightest difference other than the eyes could be found. To assume that these represent different species, particularly where the one-eyed paired forms represent two specimens in a sample of thousands, is to my view sheer folly. I feel therefore that I can state with authority that in the species I call penicula there are both two-eyed and four-eyed forms. The two-eyed forms are undoubtedly synonymous with those specimens identified by Cassagnau as Ksenmani. It is entirely possible that these two species are synonyms but before this can be ascertained the whole group must be thoroughly reviewed.

Distribution: LEBANON : Ain Z'Halte Cedars, many dates; B'Charra Cedars, V '53; Kammouha, vIII '52; Barouk Cedars, VI '53; Chamlane, XII '53; Vic. Beit ed Dine, XI '53; Beirut, American University campus, many dates. SYRIA: North Latakia pine forest, vII '53; Latakia, oak grove just below Turkish border, v'53.

\section{Folsomia candida Willem}

Folsomia candida Willem 1902. Ann. Soc. Ent. Belgique, 46:275-283.

The specimens at hand agree very well with the figures and descriptions given in Stach. The only notable difference was the absence of an inner tooth on the unguis. In this respect the present specimens are similar to Bagnall's distincta, but I agree with Stach that there is insufficent grounds for separating this species at the present time. The evidence of Delamare (1950) and this material point to a locally variable widespread form. The 
present specimens are similar to the forms described and figured from Ardeche by Delamare in the absence of an inner tooth and the proportions of the dens, as well as in the existence of an occasional triangular P.A.O. However, in the chaetotaxy of the manubrial venter and the structure of the unguis, the present specimens are much more like those figured by Stach for candida.

Distribution: LEBANON : Beirut, campus American University, V '52; between Jezzine and B'Kassine, Ix '52; Hermel, vII '52; Kammouha, vIII '52.

Folsomia cavicola Cassagnau \& Delamare

Folsomia cavicola P. Cassagnau \& Cl. Delamare Deboutteville op. cit. $: 381,382$.

I have not recovered this species but it appears to be distinguished from candida in Lebanon by the absence of an apical filament on the unguis, presence of a large internal ungual tooth, and the blunt mucronal teeth. Also the apical tooth is strongly upcurved in contrast to the straight tooth of candida. Known only from Ghita cave.

\section{Folsomia sp.}

A single specimen taken (damaged) from the Nahr Array in Lebanon merits mention. The P.A.o. is divided by a prominent listel, and the last three abdominal segments are weakly fused. The furcula is short and the mucro three-toothed. The eyes appear to be eight/side but are hard to distinguish. While this is probably a new species of Folsomia the single damaged specimen is insufficient material for its description.

\section{Proisotoma minuta Tullberg}

1sotoma minuta Tullberg 1871. op. cit. :143-155.

The specimens at hand appear quite similar to those described and figured by Linnianemi, and Stach. There appears to be some variation in the setae on the tenaculum (most of the present forms have two setae) and in the eyes. In a number of specimens it appears that eyes G. and $\mathrm{H}$ are definitely smaller than the remainder. The size of the basalmost mucronal tooth is variable.

Distribution: LEBANON :Hermel, VII ' $52 ; 2 \mathrm{Km}$. N. of Saida, XI '53; Antilias, XI '52 Nahr Array, v'52; Beirut, American University campus. SYRIA : Latakia, below Turkjah horder. Oak Grove. vII '53; North Latakia pine forest 
Proisotoma minima (Absolon)

Isotoma minima Absolon 1901. Zool. Anz.24 (634): 32,33.

Only three specimens were recovered from one locality: LEBANON: Aaranita, VII '52.

Ballisrura schötti Dalla Torre

Proisotoma schötti (Dalla Torre) 1885, 46 Progr. St. Gymn. Innsbruck.

Handschin recorded this species from Palestine.

Ballistura levantina, $n$. sp.

Plate 8, Figures 8-13

Facies Hypogastrura-like. Body and appendages thick. Uniformly blue-black in color except for slihgtly paler legs. Clothing of trunk and head of smooth, short curved setae of relatively uniform length. Sixth abdominal segment with a dozen longer setae about twice to three times as long as the shortest setae of the same segment. Antennae slightly but definitely longer than head. Fourth antennal segment without apical bulb, clothed with a variety of short, smooth setae. These are of three main types, straight to curved acuminate setae, straight truncate setae, and long mostly curved blunt "sensory" setae. In addition the dorsal surface bears a short triangular spine-like seta in a clear pit. Sense organ of third antennal segment of two oval central pegs, one of which is strongly curved. Remainder of antennae clothed with normal acuminate setae. P.A.o. elliptical, eyepatch. Tibiotarsus without subsegment. Tenent hair not clavate and unguis untoothed. Empolial appendage with large inner basal lamella and clear apical filament. Manubrion without ventral setae and with numerous torsal setae. Dentes thick but tapering. Mucro boat shaped with thick granulate central axis, and with toothed lateral lamellae. Mucro from site view very deep, more than $1 / 2$ as deep as long. Tenaculum with four teeth and a single bristle. Corpus with an anterior projection much longer than the rami.

The species is similar to $B$. crassicauda in most respects. The differences between the two species are all small but in accumulation they indicate a real difference. Since previous abundant records of the group have shown little variation I feel the differences listed below merit specific separation. 
Character mucro

manubrium

4th ant. seg.

3rd ant. seg. "sense organs" longest abdominal setae

\section{crassicauda levantina}

less than $1 / 2$ as more than $1 / 2$ as deep as long deep as long with 4 ventral setae without ventral setae without blunt with clear blunt "sensory" setae "sensory" setae peg-like, subcylin- oval drical

There is some variation in the P.A.0. of the present species. In most specimens the margins are entire but a few show clear indentation in one or both margins. In most respects there is almost no variation in the large series seen.

Known only from type locality : LEBANON : Kadischa cave; moss near spray zone of waterfall near mouth, $v$ '53 (30 specimens).

\section{Isotomina bituberculata (Wahlgren)}

Although the original description was not seen the specimens at hand agree very well with the available descriptions. The eye number is six per side. Some specimens have the eyes so heavily pigmented as to be difficult to count but observation during clearing with Potassium Hydroxide showed the actual number to six in every case examined. The posterior abdominal setae are unusually long in adults varying from .045 to $.066 \mathrm{~mm}$. This may very well be the same species described by Cassagnau and Delamare as Isotomina pontica. In some small specimens the median eyes are invisible until clearing is complete and this might account for the difference in identification. Distribution: LEBANON :2 km. E. Rayak, vII '52; Hadeth, vII '53; below Bakich, v '53; $14 \mathrm{~km}$. S. Saida, XI '53. SYRIA: Northern Latakia pine forest, VII '53.

\section{Isotomina pontica Stach}

Isotomina pontica Stach 1947. Acta Monog. Polska Akademia Umiejetnosci : 267.

Cassagnau and Delamare reported this from 3 localities: 
Grotte d'Amchite, Roum, and Source de Hasbani. See the discussion above.

Isotomina salaymehi, $\mathrm{n}$. sp.

Plate 9, figures 14-21

Body subscylindrical with last two segments solidly fused. Furcula reaching posterior border of second abdominal segment. Pigment gray, in the form of scattered granules. Eyepatches black and medially constricted. Fourth antennal segment clothed with numerous curved and straight acuminate setae. Six of these are basally slightly expanded and notably thicker than remainder. Third antennal segment with two short "sensory" oval knobs set by short stalks in separate pits. On either side a narrow rod. Remainder of antennae clothed with slightly curved to straight acuminate smooth setae. Thorax and first four abdominal segments clothed with short acuminate smooth setae, recumbent except for a single row of erect setae on the third and fourth abdominal segments. Fused fifth and sixth segments clothed with acuminate setae of various sizes, the longest 3 times as long as the shortest. In addition a single blunt "sensory" setae can be seen in the posterio-lateral quadrant on each side. Eyes eight per side with eye D strikingly smaller than remainder. Legs unpigmented with incomplete but distinct subsegment on at least one pair of tibiotarsi. Unguis with minute inner tooth but without lateral teeth. Empodial appendage

\section{Explanation of Plate 10}

Figures 26-28: Vertagopus ciliatus n. sp. 26. Right fore foot, holotype, $1000 \times .27$. Right mucro, holotype, $1000 \times$. 28. Third antennal segment "sense" organ, paratype, $1200 \times$. Figures 29-37: Pseudisotoma (Isotomida) anamola n. sp. 29. Habitus (slightly compressed in mounting) holotype, $90 \times$. 30. Fused fifth and sixth abdominal segments, paratype, 300 $\times$. 31. Right P.A.o. and anterior four eyes, paratype, $1200 \times$. 32. Third antennal segment sense organ, paratype, $1200 \times$. 33. Right hind foot, paraiype, $1200 \times$. 34. Mucro, side view, paratype, $1200 \times .35$. Mucro seen from above, holotype, $1200 \times 36$. Large clliate seta from fig. 30 showing peculiar ciliation, $1200 \times$. 37. Tip fourth antennal segment, holotype, $1100 \times$. 


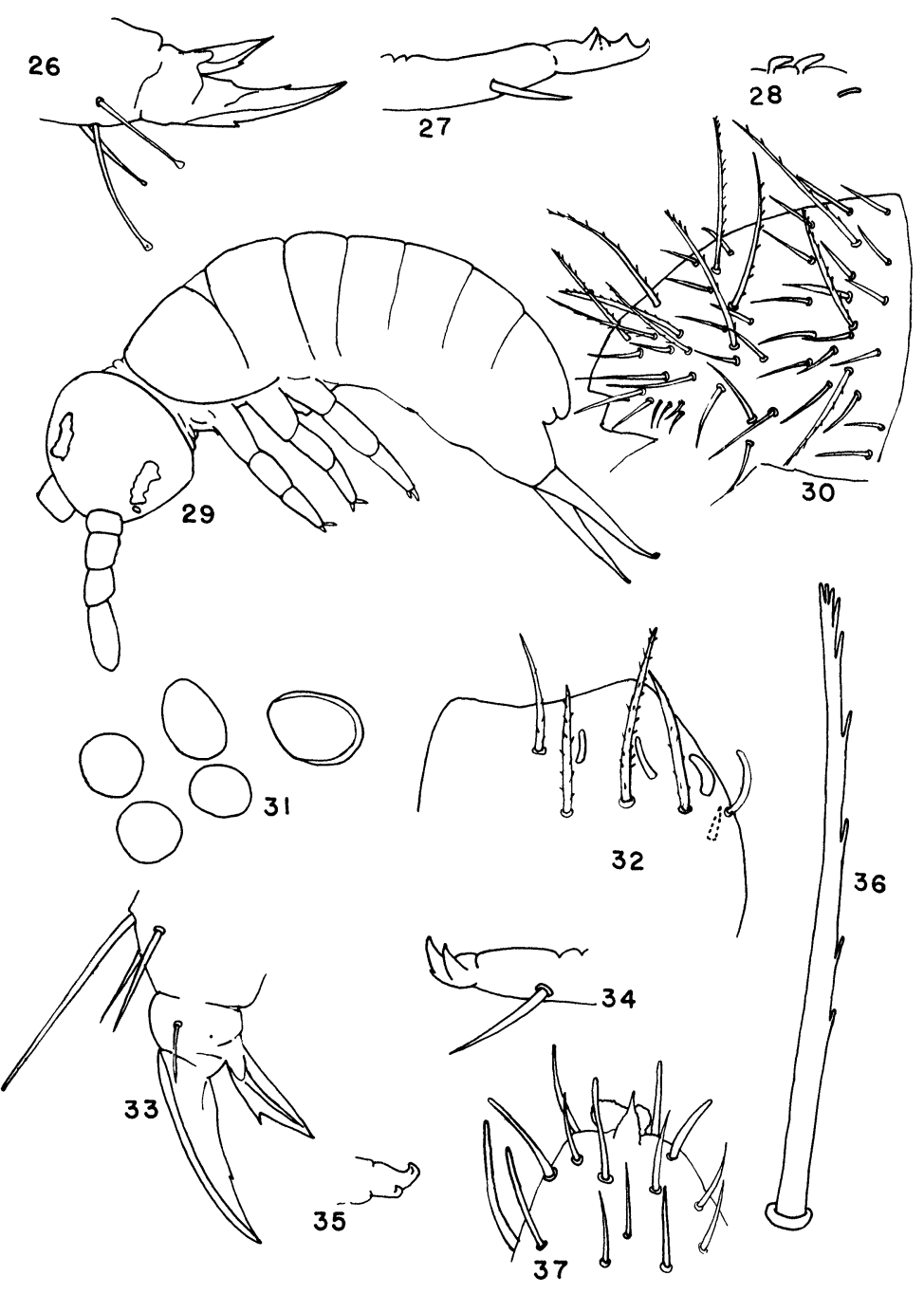

Christiansen - Collembola 
acuminate, with striking central ridge, and basal part inner lamella expanded. Tenent hair acuminate. Tenaculum with four teeth and single large basal seta. Manubrium with one pair of ventral and 24 dorsal setae. Dens with a double row of ventral setae, and four dorsal setae. Mucro with two teeth and straight ventral margin.

\section{Discussion}

This species can readily be separated from all described species of Isotomina by the well developed blunt "sensory" seta on the last abdominal segment. In other respects this species seems to be most closely related to $I$. thermophila, but it may also be separated from this species by the small eye $D$, by the presence of a tibiotarsal subsegment, and by the fact that the longest abdominal setae are three times as long as the shortest.

The present species shows a good deal of variation, particularly in respect to the eyes. The eye $\mathrm{D}$ is usually considerably smaller than the remainder but in a few specimens it is entirely absent. The eyepatch shows some tendency towards constriction in the middle, and in a few specimens it is actually divided into two patches. The clarity and presence of the tibiotarsal subsegment varies a great deal although most specimens show this on the third pair of legs.

Type locality: Antelias, Lebanon, XI '52. Other collections: Lebanon: Vic. Nabeth Safa, XI '53; Beirut, American University campus, V '52; Barouk Cedars, VI '53; $2 \mathrm{~km}$. E. Rayak VII '52. SYRIA: S. Latakia.

\section{Vertagopus aborea Linne}

Podura arborea Linne 1758. Systema naturae Edit. 10 Holmiae: 609.

The specimens at hand agree well with available descriptions and specimens except for two things: first, the color is not dark purple or purple blue but medium to pale grayblue. Second, the fifth and sixth abdominal segments have setae twice as long as the shortest setae of these segments. As Stach points out, from the varied descriptions of this form it would appear that either a species complex or a geographically variable form is involved. In view of the general similarity of the present specimens with European 
members of this species, I consider it best to place them in the same species. In the region it appears to be rare and only in the cedar forests. Distribution: LEBANON : B'Charra Cedars, v'53; Barouk Cedars, vI ,53; Hadeth Cedars, vII '53.

Vertagopus ciliatus, n. sp.

Plate 9, figures 22-25; plate 10, figures 26-28

Body subsylindrical, furcula reaching posterior border of second abdominal segment. Antennae clearly longer than head and slightly longer than furcula. Pigment dark blue in scabrous patches over antennae, head and body tergites. Legs, furcula, and venter light blue. Fourth antennal segment with two prominent apical humps and a single apical cone bearing a stout acuminate seta. Just below antennal apex a single stout curved rod and below this a distinct pit containing a spherical knob with a short curved conical seta on its basal margin. Outer margin of segment with two irregular rows of curved blunted setae. Third antennal segment "sense organ" of two strongly curved thickened knobs without clear protective setae. Remainder of antennae clothed with numerous curved and straight acuminate smooth setae. Fourth abdominal segment similar except for the posterior two rows of setae which are apically unilaterally ciliate. Fifth segment clothed with similar setae with the addition of a single row of long cylindrical setae, blunt and apically finely ciliate. Sixth segment with three rows of long setae, the anterior row similar to those of the fifth segment, the posterior two rows somewhat more acuminate. Tibiotarsus with three clubbed tenent hairs, the median strikingly longer than the others. Unguis narrow, with small internal and pronounced lateral teeth. Empodial appendage lanceolate with minute corner tooth. Eyepatch solid, eyes eight per side with eyes $\mathbf{G}$ and $\mathbf{H}$ smaller than remainder. P.A.o. oval, about as long as one large eye, with faint indication of transverse listel. Tenaculum with four teeth and five setae on corpus. Manubrium with fifteen ventral setae as follows: two transverse rows of three near apex and two converging longitudinal rows of four setae joined at a basal median seta. Dens with numerous stout acuminate ventral setae and four slender 
dorsal ones. Mucro with four teeth, apical projecting forward and slightly smaller than remainder which are subequal.

\section{Discussion}

This species appears to be most closely allied to $V$. cinerea but it may readily be separated from that species on the basis of the structure of the third antennal organ, the structure of the eyes and the peculiar abdominal setae. These setae occur on both adult males and female. These setae would appear to separate it readily from all described species of the genus. The P.A.O. usually shows some indication of a dividing listel but this may be entirely absent.

Known only from the type locality, Kammouha Spruce Forest, VIII '52,, LEBANON (8 specimens).

\section{Pseudisotoma (Istomidia) anamola, n. sp.} Plate 10, Figures 29-37

Facies isotomine. Fourth antennal segment with apical bilobed bulb and striking conical projection bearing a stout acuminate seta. Apical half of segment with a number of slightly blunted curved setae somewhat larger than remaining setae which are acuminate, smooth, curved or straight. Remaining antennal segments clothed with slightly curved mostly sparsely ciliate acuminate setae of differing sizes. Third antennal segment organ of three thick short cylindrical pegs of varying diameter, the median being the largest. In addition there is a somewhat longer slender rod. All of these are situated in a straight line without protecting folds or pits. A small conical seta is located on the opposite surface of the segment. Head and body clothed with a variety of slightly curved to straight acuminate setae. The smaller ones are smooth but the larger setae on the thorax and abdomen are unilaterally sparsely ciliate. Eyes eight per side with the anterior two larger than remainder. P.A.o. broadly oval, about as long as one forward eye. Setae of legs acuminate smooth, those on femur sparsely striate. Unguis with minute median internal tooth and distinct lateral teeth. Empodial appendage lanceolate with a clear inner corner tooth. Tenent hairs acuminate. Tenaculum with four teeth, corpus without 
setae. Fifth and sixth abdominal segments fused, remainder distinct. Manubrium slightly less than half as long as dens, dorsally with numerous setae, ventrally with a single pair of large setae near the base of the dens. Dens ventrally with numerous short acuminate setae, and dorsally with six slender short setae. Mucro short, with two large curved teeth and a minute apical tooth.

Only a few specimens of this unusual species were seen and all of these were apparently immature. The head body ratios and general condition of the animals would indicate that they were nearly adult and thus while significant change in some organs with growth cannot be ruled out (ex., manubrial chaetotaxy) it seems likely that the major characteristics described above will hold for the adult animals. The discovery of this species poses some interesting questions. If we accept the commonly used distinction between Proisotominae and Isotominae - i.e. two or less manubrial setae on venter - then this species would be in the Proisotominae and close to the genus Isotomina or Proisotoma. However, in all other structures the animal shows a clear relationship to the Isotominae, and has nothing in common with the genera mentioned above save the manubrial chaetotaxy. In the Isotominae it would appear to fall into Salmon's genus Isotomidia. This genus was created for species generally similar to Pseudisotoma except for the lack of clavate tenent hairs and the presence of papillae on the antennae. Stach, apparently feeling that this insufficient grounds for separation, placed this as a synonym of Pseudisotoma. The present species fits the criteria for Isotomidia except for the absence of the antennal papillae, and further differs from Pseudistotoma by the presence of an apical biloped bulb, and the single pair of ventral manubrial setae. In his description of Isotomidia triseta Salmon (1944) says "A few isolated setae occur on the manubrium ..." and in his figures he shows what might be considered an apical bulb. In view of this and the differences between the two forms I have thought it best to consider Isotomidia a subgenus of Pseudistoma unt:l a thorough study of all the forms can be made.

The species has been taken from two localities in 
LebANON: Type locality: Wadi Jahnam (N.W. Tripoli province), VII '52 (2 specimens). Also taken from $2 \mathrm{~km}$. E. Rayak, vII '52.

Isotoma notabilis Schaeffer

Isotoma notabilis Schaeffer 1896. Mitt. Naturh. Mus. Hamburg 13:187.

The specimens at hand agree well with available descriptions and specimens of the species. A few minor chaetotaxy differences could be seen, notably the absence of a pair of long setae on the second and third abdominal segments. A few specimens showed three eyes per side rather than the normal four. The species is widespread throughout Lebanon and Latakia but is oddly absent from the coastal plain area.

Distribution: LEBANON : Hadeth Cedars, vII '53 ; B'Charra Cedars, IV '53, Ain Z'Halte Cedars, VII '52 \& XI '52 ; Kammouha, VII '52; Barouk Cedars, VI '53; below Bakich, V '53; Souk el Gharb, VIII '53; Vic. Beit ed Dine, XI '53; Bikfaya, vIII ' 53 ; 2 km. E. Rayak, vII '52; Antelias source, XI '52; Rahbeh B'kaa, IX '52. SYRIA: Latakia, oak grove below Turkish border.

\section{Isotoma viridis Bourlet}

Isotoma viridis Bourlet 1839. Mem. Soc. Roy. Sci. Agric. Arts Lille :401. Isotoma turkestanica Stach 1947. op. cit. :355, 366. (NEW SYNonYMY).

The specimens agree on the whole very well with figures, descriptions and specimens previously identified as this species. Certain variations are worthy of note. First there are on most specimens clearly visible fine ciliate setae on the dens. In addition to this about half the specimens have the anteapical teeth not on a level. A last character of note is the P.A.o. In most, but not all, specimens this organ has a thickened margin of irregular shape. The pattern of the specimens is either of the type called decorata by Brown or in the form of stripes across the posterior margins of the segments.

The occurrence of the ciliated dental setae and the displaced anteapical tooth raises a serious question in connection with Stach's I. turkestanica. This form, briefly described in his key and without figures or further description in the text, differs from viridis by the occurrence of ciliated setae on the dens and the feet. In addition he 
mentions the fact that the anteapical teeth are not on a level. In the specimens seen here the ciliate setae can be seen on the dens but not the legs while the teeth may or may not be level. In addition there is the variation in the structure of the P.A.o. not mentioned before. When we combine this with the well known local variability of the pattern in viridis I feel it best to consider turkestanica and the present form part of the locally variable widespread I. viridis.

In the region it has been found only from the Lebanon Mountains: LEBANON : B'Charra Cedars, v '53; Vic. Harrisa, XI '52; Ain Z'Halte Cedars, vII '52 \& XI '52. Cassagnau \& Delamare reported it from Chebaa and Handschin from several localities in Palestine.

Isotomuris palustris Muller

Podura palustris Muller 1776. Zoologicae Daniae Prodremus :184.

The specimens agree well with available descriptions of European forms identified as this species, A number of minor differences are seen: there are frequently no ciliate macrochaetae on the third abdominal segment, and the corner tooth on the last two pairs of empodial appendages is absent in about $85 \%$ of the animals. The patterns are varied. Distribution: LEBANON: $2 \mathrm{~km}$. S. Saida, XI '53; Ain Z'Halte, XI '53; Ain Z'Halte Cedars, v 'EC; Kammoutha, VIII '52; Vic Quaaranita, VII '52; Wadi Jahanem (N.W. Tripoli province), VII '52; Vic. Beit ed Dine, XI '53; Harajel, XI 'EB; Chamlane, XII '53.

Literature Cited (see also parts I and II)

AGRELL, I.

1939. Ein Artenproblem in der Collembolengattung Folsomia. Kungl. Sall. Forh. 9 (13) :1-14.

1948. Studies on Postembryonic development of Collemboles. Arkiv. Zool. Kongl. Svensk. Vet. 41 (12):1-35.

Delamare Deboutteville, Cl.

1950. Notes faunistiques sur les Collemboles de France. VII. Collemboles de la Grotte de la Balme. Bull. Mens. Soc. Lnn. Lyon $19(6): 122,123$.

Gisin, H.

1942. Materialen zur Revision der Collembolen: I. Neue un Verkannte Isotomiden. Rev. Suisse de Zool. 49 (20):288-290. 
1944. Materialen zur Revision der Collebolen. II. Weiteres Basaler Material. Mitt. Schweiz. Ent. Ges. 19(4-5) :21-25.

1946. Collemboles nouveaux ou peu connus de la Suisse. Mitt. Schweiz. Ent. Ges. 20(3):219,220.

1957. Sur la faune europeene des Collemboles. I. Rev. Suisse de Zoologie 64(25):486-488.

Kseneman, $M$.

1936, Zur Bestimmung aller bisher bekannten Arten der Gattung Folsomia Willem. Sborn. Cs. Acad. Zemed. Prague 11:210-219.

1936. Diagnosen neuer Collembolenarten aus Mitteleuropa. Op. Cit. :101-108.

Linnaniemi, W. M.

1912. Die Apterygotenfauna Finlands. II. Spezialer Teil. Acta Soc. Sci. Fenn. 40(5) :1-352.

SALMon, J. T.

1944. New Genera, Species and Records of New Zealand Collembola Rec. Domin. Mus. $1: 123-182$. 

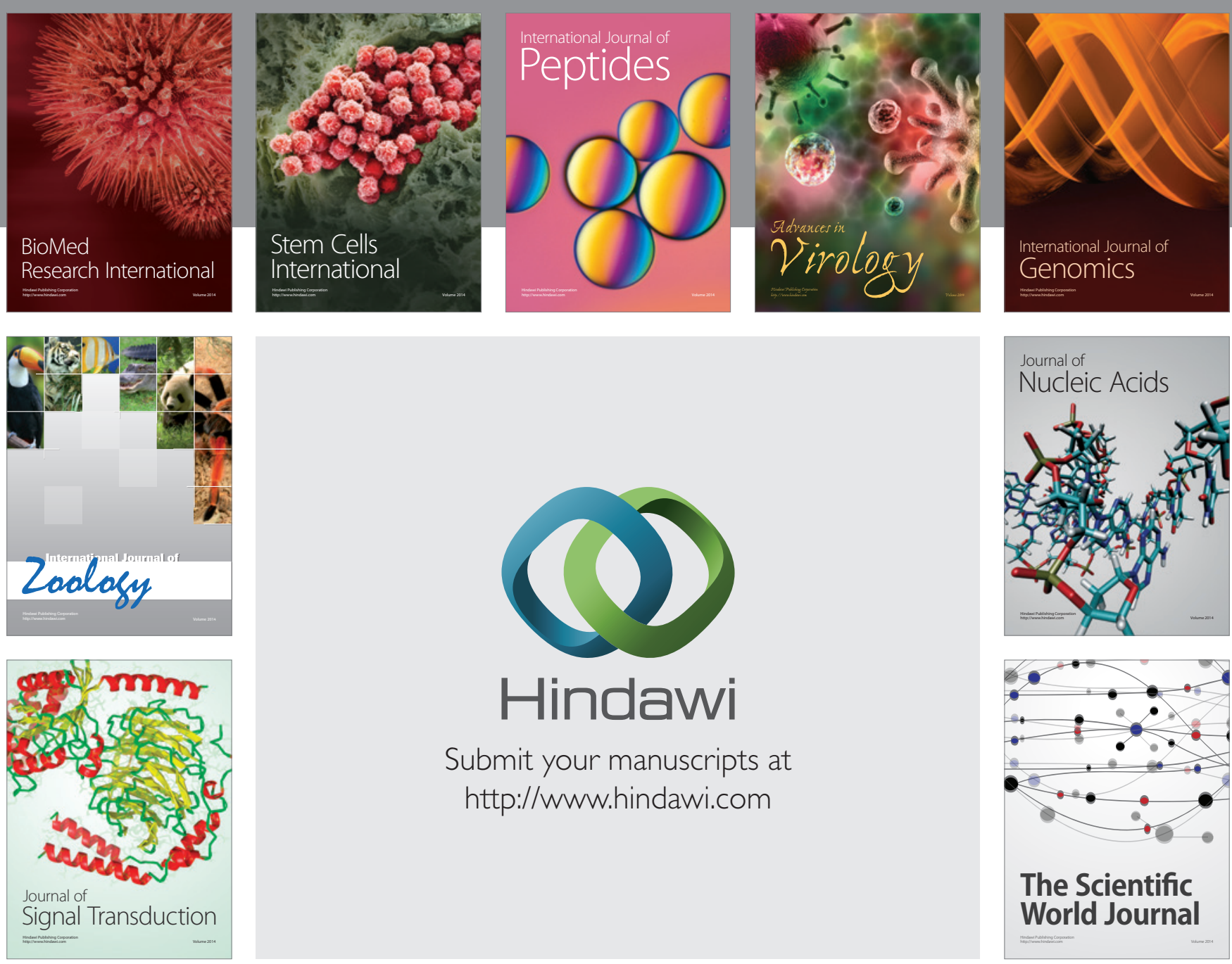

Submit your manuscripts at

http://www.hindawi.com
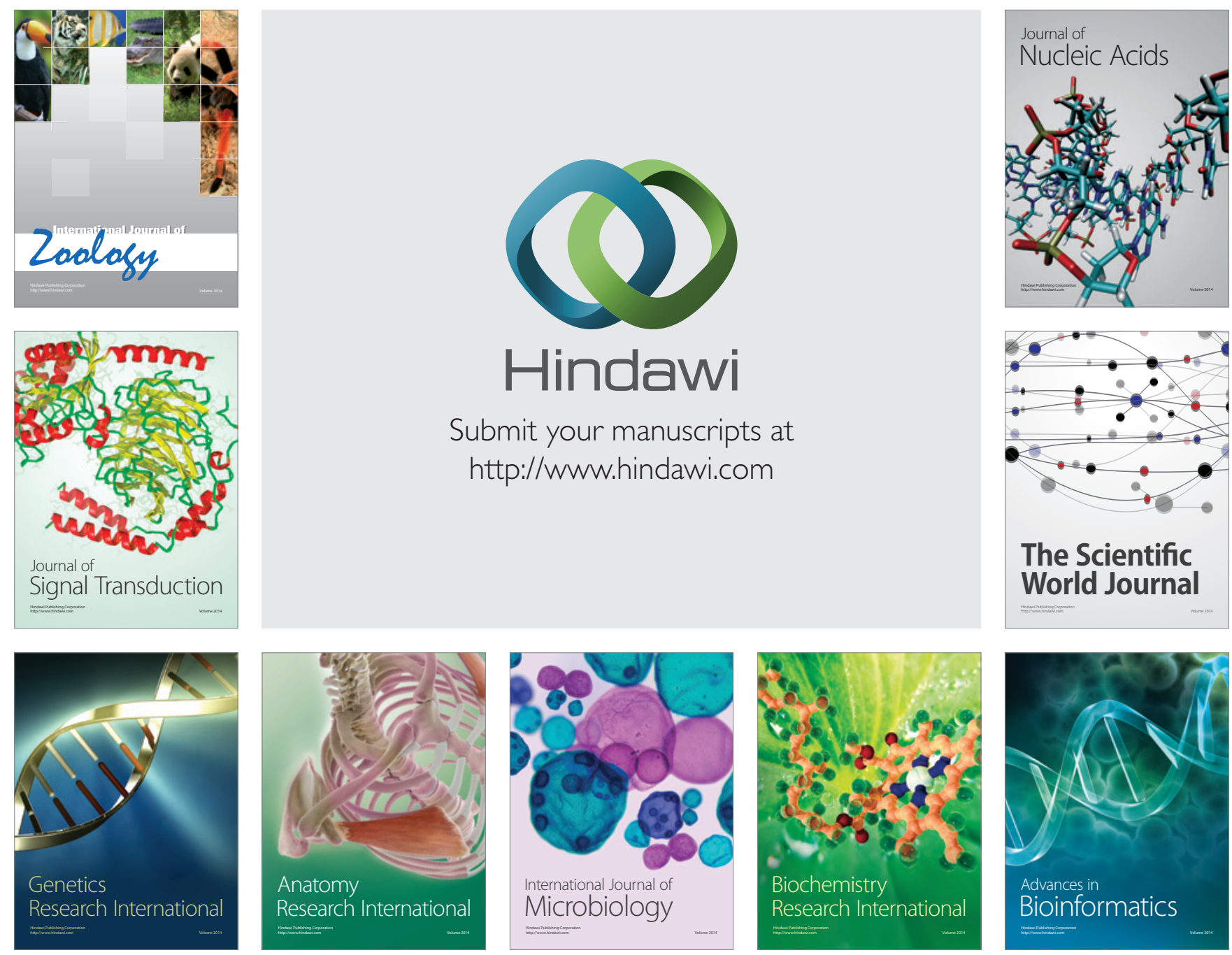

The Scientific World Journal
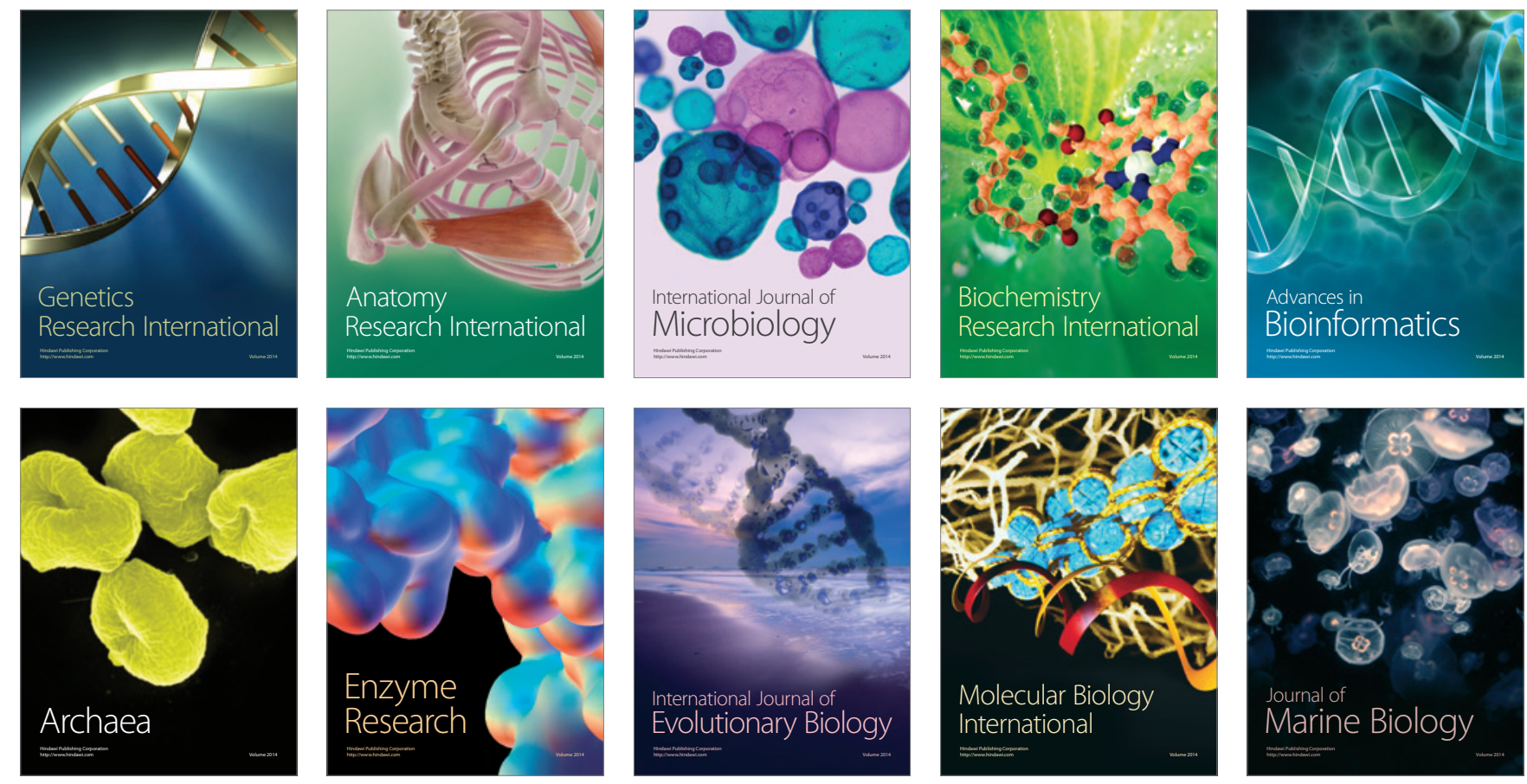